\title{
The Influence of YouTube for Music Industry in a Digital Era
}

\author{
Reni Diah Kusumawati ${ }^{+}$, Teddy Oswari, Tristyanti Yusnitasari, Singgih Wisnu Pranata ${ }^{+}$ \\ Gunadarma University, Indonesia
}

\begin{abstract}
The development of social media and the increasing number of Internet users, give the opportunities for musicians and music industry in Indonesia utilizing the media for promotion. YouTube is one of the social media chosen by musicians to introduce their music by uploading video clips or video performances of the song they want promoted. YouTube visitor numbers are increasing every year and it expected can help musicians to introduce their works to public. This study aims to determine how the role of YouTube for musicians in introducing the works of musicians to community, and to know how big the role of YouTube as a promotion media in helping the music industry in Indonesia. This study was conducted by interviewing musicians and music business personnel to gauge the perspective of musicians which are involved in promotion online using YouTube, in order to determine the role of YouTube to promote the works of musicians. The results indicate that YouTube gives musicians a very helpful role in promoting the musician's works in Indonesia.
\end{abstract}

Keywords: promotion, music, youtube

\section{Introduction}

Media technology is growing in people's lives, it shows by the expanding use of Internet in society, and Internet became the most media which is widely consumed by people in Indonesia [1]. Internet can be used as a media of information, communication, study, entertainments, and it also can even be used as a medium for promotion. The development of information technology has unwittingly forming human communities that live in two worlds of lives, that was real life and virtual (cyber community). One community facility in the virtual world of online socializing can be done through online social media. Online social media is an interactive media designed to facilitate social interaction with the Internet-based technology.

In this internet era, online social media types are very diverse, and one of the most popular is YouTube. Since the launch of YouTube in 2005, the world has witnessed a remarkable community with more than 72 hours of video are uploaded every minute. The main function of YouTube social media is to apply an object that can be watched by the media user, this could be create the perception of everyone on YouTube social media is different. YouTube utilization related to the music world such as the emergence of Justin Bieber popular through YouTube. YouTube phenomenon proves that online social media exposure is very influential in the community that could ultimately affect one's popularity. YouTube is now also beginning to be used by musicians to introduce their songs and shows the vocal and musical abilities of the musicians. YouTube is very popular because music lovers are not only listening to the songs of the musician, but also can see a video clip of the musicians.

\section{Literature Review}

YouTube is one of the online social media that can be used by the music industry for promotion. Experts believe that the recording label will pursue a strategy of avoiding risk in the promotion by only focusing on marketing with mass appeal and huge sales potential [2]. The use of right marketing strategy for the music product will be able to reach the consumer, so that consumers know the songs by musicians. The music industry hopes various marketing strategies undertaken will be able to increase sales of music products [3].

\footnotetext{
${ }^{+}$Corresponding author.

E-mail address: reni_dk@staff.gunadarma.ac.id, singgihwisnupranata@ student.gunadarma.ac.id
} 
Promotion as one of the tools of marketing strategy can be performed by musicians by using internet media. Promotion mix consists of advertising, sales promotion, personal selling, publicity, and direct marketing can be done via the internet. Previous research identified sales promotion as the main activities that can be done in marketing activities to assist the organization in achieving its goals [4]. The purpose of sales promotion is to motivate customers to buy the product to increase sales volume [5] [6] [7].

The internet growth gives the opportunity for music industry to innovate in promoting the new song, and it can increase the sales volume of song being promoted [8]. Utilization of social media as a platform for the promotion by showing video clips of the songs performed will be able to attract consumer to raise the popularity of musicians and can increase the sales volume of musicians [9]. Publicity through social media can influence consumer decisions that can be increase sales volume [10]. Although today consumers begin to migrate to digital, but the music industry believe that physical album of musicians will not disappear or be destroyed, because there are people who still buy it though not for everyday consumption, but to a private collection. Consumers assess no difference in terms of quality between the music product of CDs and online music product [11], but there is no doubt that technology is growing and physical albums that are quite expensive will gradually begin to be abandoned.

The era of Internet video entering a golden age, where Internet users are more interested in watching a variety of information, both to watch and to see the entertainment news [12]. YouTube fame has even been used as a barometer for the popularity of artists and celebrities in the world. People will easily become very popular just by uploading their videos through YouTube. These technological advances make musicians more accessible to the audience, and the audience is also more accessible to musicians [13]. Online streaming video service for free on YouTube has been used by artists to share and present their artwork [14]. YouTube celebrities have appeared like a virus, received national and international attention through their works and spread rapidly like a virus through social media [15]. YouTube is not only used by musicians who are already known by the public, but also can be used by independent musicians to promote their works to public [16]. Distribution via internet and advertising through social media gives musicians and music industry a means to promote their works to global audiences [17].

International Federation of the sound recording industry shows that YouTube is the preferred service for listening the music among teenagers and an option to view music videos online. YouTube became one of the distribution channels to introduce a music to the audience though only provide low profit margins [18]. In the digital market of social media, the artist must be able to maintain their charm and their image as the star [19], and the recording industry should be able to offer something new to be able to anticipate the growth of the consumer market [20]. Based on the explanation, the purpose of this study was to determine how the role of YouTube for musicians in introducing the works of musicians to the community, and to know how big the role of YouTube to increase music sales volume to raise the music industry in Indonesia.

\section{Research Method}

The populations in this study are musicians and music business personnel, with the number of samples are 100 respondents. Research instrument used was a questionnaire. Likert scale $1-5$ is used as a measurement in this research. Hypothesis used in this research is multiple regression analysis techniques.

The grant theory in this study is the Theory of Planned Behavioral [21], who postulated three free concepts that determine the intention, that are attitudes, norms, and behavior control. Another grant theory of this research is a model of consumer behaviour [22], which explains that the behavior of consumers in the purchase of goods or services affected by marketing stimuli, other stimuli, and consumer characteristics. The research model used is a modification of a previous study that discussed about promotion mix, and sales volume [7] [8].

\section{Result and Discussion}

\subsection{Result}

The result of validity test for promotion mix variables and sales volume showed significant values $(\mathrm{p}<0.05)$, this value means that all questions items in questionnaire are valid and can be used in research. 
Reliability test results for promotion mix variables and sales volume showed value $>0.60$, which means that the data from the questionnaire can be trusted. Simultaneous test results ( $F$ test) for four variables of promotion mix (advertising, sales promotion, publicity, direct marketing) and sales volume of music product as presented on Table 1.

\begin{tabular}{llll}
$\mathrm{F}$ & $\mathrm{t}$ & Sig. & R Square \\
\hline 31.300 & & $.000^{\mathrm{a}}$ & \\
& -.325 & .746 & .569 \\
& 2.893 & .005 & \\
1.399 & .165 & \\
& -.225 & .823 & \\
& 3.027 & .003 &
\end{tabular}

a. Predictors: (Constant), Direct Marketing (X4), Advertising (X1), Sales Promotion (X2), Publicity (X3) b. Dependent variable: Sales Volume (Y)

The above table shows that the value of sig. $F$ is smaller than 0.05 , the value indicates that simultaneously the variables of promotion mix (advertising, sales promotion, publicity, and direct marketing) have an affect on sales volume of music. The $\mathrm{R}$ squared value shows a value of 0.569 , which means that contribution of the influence promotion mix variables consists of advertising, sales promotion, publicity, and direct marketing to music sales volume is $56.9 \%$. This study aims to determine how the role of YouTube for musicians in introducing the works of musicians to the community, and to know how big the role of YouTube in helping the music industry in Indonesia to be able to rise and shine back in their own country. YouTube is a social media which contains the world's largest video, and the estimated millions of visitors and video, so YouTube is widely used by musicians to share and present their artwork [12].

\subsection{Discussion}

Test result on advertising variable either partially and simultaneously has an affect on music sales volume. The results indicate that the song and music video which is available on YouTube will affects on music sales volume, such as the famous of songs and musicians in the community. YouTube content of song and music video can provide information to YouTube visitors about the content of the song. The result is consistent with previous research which stated that advertising is one of the tools of promotion mix for consumer consideration [8], so consumer interested to the song and that can increase music sales volume. Result test partially for sales promotion has no significant affect on music sales volume, but simultaneously has significant affect on music sales volume. The result indicates that although the musicians also doing sales promotion on YouTube, but this should not be the primary consideration of consumers to be able to increase music sales volume. The result is not consistent with the previous researcher which state that consumers assume that sales promotion is very important in marketing activities that could affect consumers [5] [6] [7] [8].

The result for publicity variable state that partially promotion has no significant effect on music sales volume, but simultaneously publicity variable has significant affect on music sales volume. The result indicated that even YouTube provide convenience to be able to comment on the song and can interact with the musicians through YouTube, but it has not been able to increase on music sales volume. The result is consistent with the previous research which stated that publicity through social media can't influence the consumer's decision to increase sales volume [11]. The result on direct marketing either partially and simultaneously has an affect on music sales volume. The result indicated that completeness of information on YouTube about a song and ease to download songs from YouTube can increase music sales volume. The increasing of music sales volume can be seen by the increasing number of musician invitation to perform on music shows both on air and off air. The result is consistent with the previous research which stated that direct marketing can be done to arouse the consumer interest to increase number of sales volume [8].

Music is the most selection of requested by internet users because through YouTube everyone not only listen the songs, but also can see the singer who sings the song being sung, sometimes even Internet users 
who saw the music video through YouTube can also see the lyrics of the song being displayed. YouTube not only for musicians who are already known by the public, but also can be used by newcomer musicians to introduce their works to the public. Every musician either already known by the public and the musicians newcomers can conduct a promotion of their song by utilizing YouTube [14]. Although YouTube is a social media accessed by many internet users, but it is not easy for newcomer musicians to promote through YouTube, except the musicians who were knows at the community, so the Internet users will be interested in finding information about the musicians.

The use of the right marketing strategy will be able to introduce the work of musicians to the public, since the era of the Internet is able to reach consumers widely [3]. Advances in technology are indicated by the widespread use of the internet which makes musicians are now more accessible to the audience, and the audience is also more accessible to musicians [11]. The advancement of technology facilitates the music industry to distribute their products, and YouTube become one of distribution channels option to introduce music to the audience [15][16]. YouTube also give the appearance of losses for the music industry where consumers who liked the song sees through YouTube will search the song and easily copy without requiring the approval of a musician or creator. Digital music content is often distributed illegal (pirated) and is often regarded as a threat to the income of producers and musicians because this content is an almost perfect substitute and consumers may decide to no longer purchase original music products.

The ease of musicians to introduce their music through social media was not followed by ease of musicians to campaign the consumers to buy their music legally. YouTube as a good medium in introducing songs and video clips of musicians can also kill the desire of consumers to buy music products of musicians, because consumers can download songs for free via internet or even find enough to see it through YouTube. This is why legal music sales are still very low compared to the ease of obtaining music illegally. According to musicians and music business personnel, in recent years YouTube are helpful in reducing illegal downloading of music and can be used to introduce new songs of the musicians. Mucisians who are already known by the public can use YouTube as a medium to promote their latest work, due to the known extent of the musician's work, these can increase the bids for these musicians to perform, both on air and off air. This opportunity is also open to new musicians who want to introduce their songs to the public. In addition to its wide range and quick in introducing the song of musicians, YouTube was also chosen because of its low cost. Many musicians who are only use their smart phones to record a video and upload it to the YouTube. They can record their videos in the music studio and even in their room, of course, it makes easier for musicians who want to introduce their song but have limited funds. YouTube was instrumental in generating the music industry, especially in Indonesia, seen from the works of musicians who appear on YouTube, and watched repeatedly by Internet users.

\section{Conclussions}

The study used four promotions mix variables to determine music sales volume. Simultaneous test results showed that all the variables of promotion mix consisting of advertising, sales promotion, publicity, and direct marketing have significant affect on music sales volume. The results showed that YouTube gives an important role in introducing the works of musicians in Indonesia, seen with increasing YouTube users in Indonesia with a duration watch music that continues increase every year. These results can be said that YouTube is very helpful in developing the music industry in Indonesia. Results of this study are expected in the future to help the music industry in establishing appropriate marketing strategies to take advantage of technological developments, such as the use of various social media to introduce the works of musicians. For music lovers, the results of this study are expected to help music lovers to appreciate the work of musicians by not consuming the music product illegally so the number of illegal music downloading can be suppressed.

\section{Acknowledgements}

The author would like to thank to Gunadarma University for its support in this study. The authors also thank to Singers and Band for their help as mediation between the writer and musician. The authors also thank colleagues for input and support, and we also thank to musicians and the music business personnel for their time in giving information related to this study. 


\section{References}

[1] Hadi, Syamsul. Perilaku Penggunaan Internet sebagai Sumber Informasi. Skripsi, Bogor: Institut Pertanian Bogor, 2006.

[2] Vaccaro, Valerie L. and Cohn, Deborah. The Evolution of Business Models and Marketing Strategies in the Music Industry. The Industry Journal on Media Management. 2004, 6 (1-2), 46-58.

[3] Gamal, Ashraf El. The Evolution of the Music Industry in the Post-Internet Era. Thesis, Claremont McKenna Colleges, 2012.

[4] Oyedapo W.O, Akinlabi B.H and Sufian J.B. The Impact of Sales Promotion on Organization Effectiveness in Nigeria Manufacturing Industry. Universal Journal of Marketing and Business Research. 2012, 14, (128-131).

[5] Syeda N.Z and Sedia M. Impact of Sales Promotion on Organizations' Profitability and Consumer's Perception in Pakistan. Interdisciplinary Journal of Contemporary Research in Business. 2011, 3 (5).

[6] Odunlami IB, Ogunsiji A. Effect of Sales Promotion as a Tool on Organizational Performance. Journal Emerg. Trends in Econ. And Manage. Sci (JETEMS). 2011, 2 (1), (9-13).

[7] Amusat, W.A, Adejumo, D.A, Ajiboye, F.A. Sales Promotion as an Antecedent of Sales Volume: A Study of Selected Manufacturing Industry in IBADAN, South Western, Nigeria. 2013, 4 (11), pp. 465-474.

[8] Kusumawati, Reni D., Purnamasari, D., Sardiyo. Innovation and Promotion Activities in the Internet to Increase Sales Volume of Music Product Using Augmented Reality. Egitania Sciencia Journal. 2013, 13 (7).

[9] Kusumawati, Reni D., Indrayani E., Harmadi, A. Utilization of Technology to Increase Music Product Sales in Indonesia. Global Journal Business Information System. 2013, 1 (1).

[10] Kusumawati, Reni D., Prijanto, B., Noviana, S. Promotion Mix in The Internet as An Effective Tool to Influence Purchasing Decision of Ring Back Tone (RBT). Clute Institute International Conference. 2012, March.

[11] Kusumawati, Reni D., Arianty, R., Susetianingtias, D.T. Consumer Perception on Music Products: CD vs Online. Journal of Applied Sciences Research. 2015, 11 (15), 23-28.

[12] West, Tyler. Going Viral: Factors That Lead Videos to Become Internet Phenomena. The Elon Journal of Undergraduate Research in Communications. 2011, 2 (1), pp. 76-84.

[13] Baym, N. K. Fans or Friends?: Seeing Social Media Audiences as Musicians Do. Journal of Audiens \& Reception Studies. 2012, 9 (2), 286-316.

[14] Cayari, C. The YouTube Effect: How YouTube Has Provided New Ways to Consume, Create, and Share Music. International Journal of Education \& the Arts. 2011, 12 (6), 1-30.

[15] Broxton, T., Interian, Y., Vaver, J. \& Wattenhoffer, M. Catchin a Viral Video. Journal of Intelligent Information System. 2013, 40 (20), 241-259.

[16] Rocca, Lisa L. Has the Independent Musician Been Empowered? Analyzing the Use of Internet Technologies for Music Promotion. Proceedings of the Technology \& Emerging Media Track. Annual Conference of the Canadian Communication Association. 2014.

[17] Hracs, B., Grant, J., Haggett, J., and Morton, J. A Tale of two Scenes: civic Capital and Retaining Musical Talent in Toronto and Halifax. The Canadian Geographer. 2011, 55 (3), pp. 365-382.

[18] Oh, Ingyu dan Lee, Hyo-Jung, Mass Media Technologies and Popular Music Genres: K-pop and YouTube. Korea Journal, 2013, 53 (4), 34-58.

[19] Ferri, Anthony. J. Emergence of the Entertainment Age?. Society. 2010, 403-409.

[20] Margiotta, Michael, Influence of Social Media on Management of Music Star Image. The Elon Journal of Undergraduate Research in Communication. 2012, 3 (1), 5-13.

[21] Ajzen, Icek. The Theory of Planned Behavior, "Organizational Behavior and Human Decision Process. 50, 179211, University of Massachusetts at Amherst, 1991.

[22] Kotler, Philip. Manajemen Pemasaran Analisis Perencanaan Implementasi dan Kontrol. Jilid 1, PT. Prehalindo, Jakarta, 1997.

[23] Ghozali, Imam. Aplikasi Analisis Multivariat dengan Program SPSS. Badan Penerbit Universitas Diponegoro. Semarang. 2002. 